\section{A new species of Ceryx Wallengren (Lepidoptera: Arctiidae: Syntominae) from the Kumaon Himalaya, India}

\section{Peter Smetacek}

The Retreat, Jones Estate, P.O.Bhimtal, Nainital, Uttarakhand 263136, India

Email: petersmetacek@rediffmail.com

The genus Ceryx Wallengren is a large genus, with representatives in south and west Africa, through Asia, to Australia. Hampson (1892) reported C. hyalina Moore, C. diptera Fabricius (as Syntomoides incipiens Walker and Syntomoides brachypecten Hampson) and C. cherra Moore (under Syntomis Ochsenheimer) from the Indian subregion. None of the above mentioned species were reported from the western Himalaya.

The following is a description of a new species recorded in the western Himalaya, which bears the characteristic hindwing venation lacking veins 3, 5 and 6 (Fig. 1) that distinguishes the monobasic Syntomoides Hampson, Ceryx and Auriculoceryx Holloway from other genera of the sub-family Syntominae. Syntomoides is monobasic, differing from Ceryx in certain features of the male genitalia. Males of the genus Auriculoceryx have filiform antennae. From the illustration of the hindwing venation of $S$. imaon in Hampson (1892) and Holloway (1988), the present species differs in having vein 4 straight rather than arched.

The type material of this and other taxa described by

Date of publication (online): 26 May 2010

Date of publication (print): 26 May 2010

ISSN $0974-7907$ (online) | 0974-7893 (print)

Editor: K. Gunathilagaraj

Manuscript details:

Ms \# 02306

Received 07 September 2009

Final received 07 April 2010

Finally accepted 14 April 2010

Citation: Smetacek, P. (2010). A new species of Ceryx Wallengren (Lepidoptera: Arctiidae: Syntominae) from the Kumaon Himalaya, India. Journal of Threatened Taxa 2(5): 894-895.

Copyright: () Peter Smetacek 2010. Creative Commons Attribution 3.0 Unported License. JoTT allows unrestricted use of this article in any medium for non-profit purposes, reproduction and distribution by providing adequate credit to the authors and the source of publication.

Acknowledgement: I am indebted to Drs. I.J. Kitching and M. Honey of the Natural History Museum, London, U.K., for comparing photos of $C$ mirabilis with material in the museum collection and to the Rufford Small Grant Foundation, U.K. for financial support that made this work possible.

\section{OPEN ACCESS | FREE DOWNLOAD}

the author (Neptis miah varshneyi; Neptis clinia praedicta; Comostola hauensteini; Dysaethria himalayica, etc.) are in the author's personal collection at the Butterfly Research Centre, The Retreat, Jones Estate, Bhimtal, Uttarakhand. This collection is the only Indian insect collection on open public display. Some types, eg. of Neptis miah varshneyi (paratype) and Neptis clinia praedicta (holotype) have been deposited in the Indian National Forest Insect Collection at the Forest Research Institute, Dehra Dun, Uttarakhand. Other type material may be deposited in that depository in future, pending a change in chemical preservatives used in that institution.

\section{Ceryx mirabilis sp. nov.}

(Fig. 1, Images 1-2)

\section{Material Examined}

Holotype: Male, 30.viii.2008 Shyamkhet 2000m, Nainital District, Uttarakhand, India. Legit et collectavit, Peter Smetacek, The Retreat, Jones Estate, Bhimtal, Uttarakhand, India; Reg.no. 1-TS-2009.

Paratypes: 3 exs.: 1 female, same data as holotype; 1 pair 11.ix.2008 in the same locality. Leg. et Coll. Peter Smetacek, The Retreat, Jones Estate, Bhimtal, Uttarakhand, India. Reg.no. 2-TS-2009 (female, 30.viii.2008); 3-TS-2009 (male, 11.ix.2008); 4-TS-2009 (female, 11.ix.2008) respectively.

\section{Etymology}

In Latin, mirabilis means "wonderful".

\section{Forewing Length}

Holotype: $11 \mathrm{~mm}$; Paratypes: $11 \mathrm{~mm}$.

\section{Description}

Holotype: Head black with a pair of yellow spots on collar; antennae minutely serrate; thorax and abdomen black with a pair of subdorsal yellow lines extending from

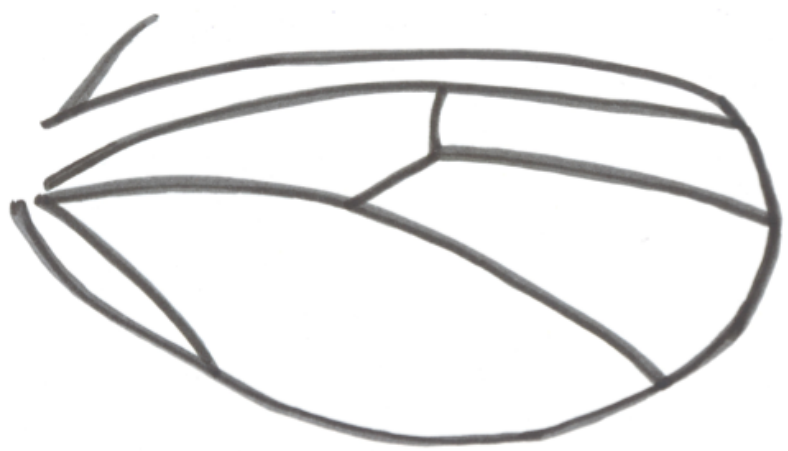

Figure 1. Hindwing venation of Ceryx mirabilis. 


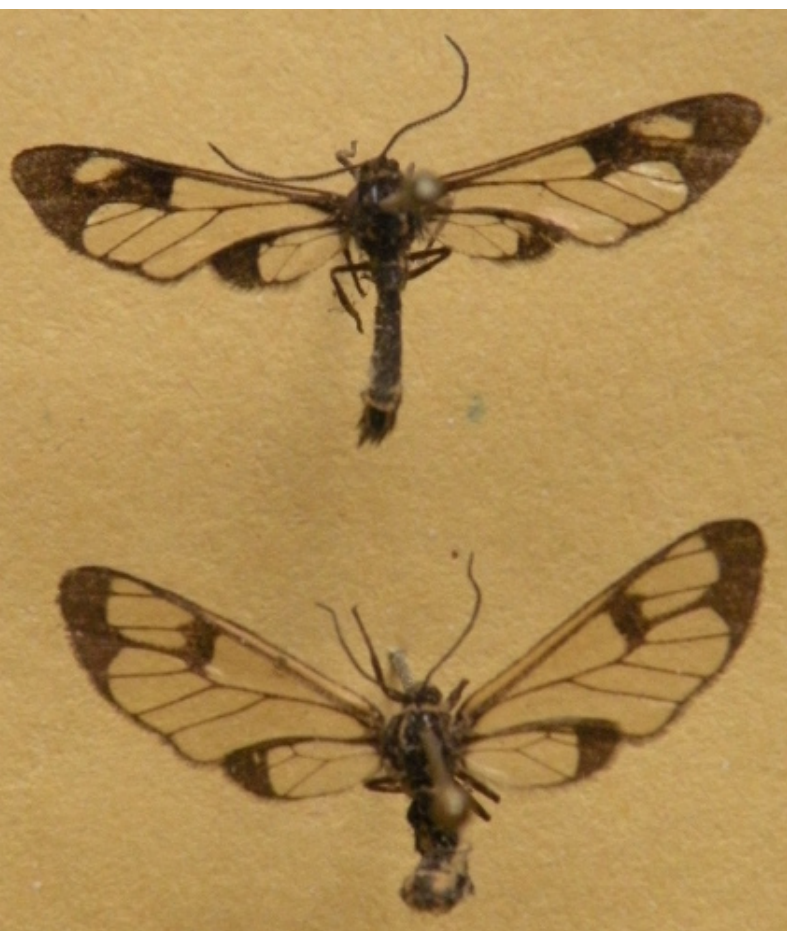

Image 1. Ceryx mirabilis holotype (1-TS-2009) above, paratype female (2-TS-2009) below.

collar to ultimate abdominal segment; abdominal segments fringed with yellow between these lines; abdomen with a yellow ventral line.

Forewing recto hyaline; costa narrowly black, leaving a hyaline streak between it and the upper vein of the cell extending from the base to discocellulars; veins black; broad black bar on discocellulars; margin narrowly black from termen to vein 3 , widening above that so that the entire area beyond the discocellulars and above vein 4 is black, except for a small subapical hyaline patch.

Hindwing with only two veins arising from the hindwing cell apart from Rs; recto surface hyaline, costa and outer third of wing black.

Paratypes: Female differs from the male in the following points: antennae simple, the collar yellow; forewing recto broader, with reduced black area on outer half, the marginal black area connected to the discocellular bar by a narrow black bar along vein 5; subapical transparent patch large and quadrate.

\section{Habitat}

The type material was recorded on the roadside in the upper part of the village of Shyamkhet between Bhowali and Ramgarh. Both pairs were recorded within a kilometer of each other. Although roadside swards in the area are typically degraded during other seasons, during the monsoon months they support lush vegetation, especially stinging nettles (Urtica and Girardinia), dock (Rumex) and other herbs. Forests at the edge of the village consist mostly of Chir Pine (Pinus roxburghii) and Himalayan Oak (Quercus spp.).

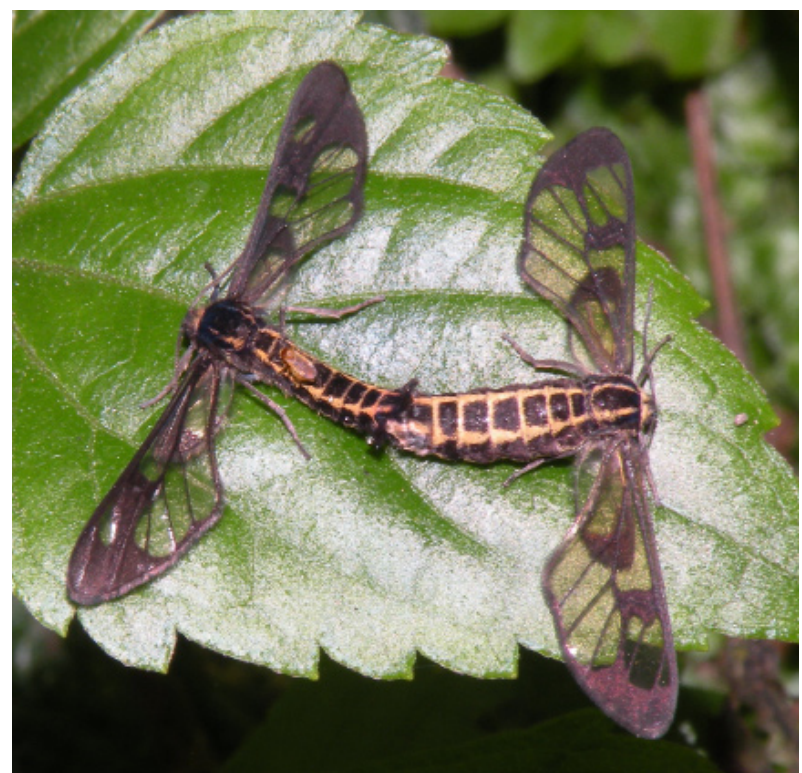

Image 2. Ceryx mirabilis holotype (1-TS-2009; left) and female paratype (2-TS-2009); right) in copula; holotype bears an insect parasite on proximal part of abdomen.

\section{Remarks}

The minutely serrate antennae of the male preclude mirabilis from being placed under the S.E. Asian Auriculoceryx Holloway. The unusual abdominal markings immediately distinguish this species from other members of the genus. Drs. lan Kitching and Martin Honey kindly compared photos of the type of mirabilis with material in the collection of the Natural History Museum, London and ascertained that there is nothing similar there.

Both the pairs comprising the type series were taken in copula, settled on low growing plants. No other individuals of this species were seen. It is on the wing briefly towards the end of the southwest Monsoon and so far has only been recorded from the village of Shyamkhet, although nearby localities at similar elevation in the same mountain range (eg. Nainital 1800-2200 m, Bhowali 1700$1750 \mathrm{~m}$, etc.) have been surveyed often over a period of many years. It has not been recorded at artificial light, although the closely related Syntomoides imaon Cramer is frequently recorded at light at lower elevation in the area (Bhimtal valley).

\section{REFERENCES}

Hampson, G.F. (1892). The Fauna of British India including Ceylon and Burma. Moths Vol. 1. Taylor and Francis, London, 22+609pp.

Holloway, J.D. (1988). The Moths of Borneo. Part 6 Arctiidae: Syntominae, Euchromiinae, Arctiinae, Aganainae (to Noctuidae). Southdene Sendirian Berhad, Kuala Lumpur, $101 \mathrm{pp}+168$ figs+6pls.

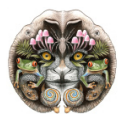

